\title{
Potensi Inokulan Petrofilik dan Kompos Kotoran Ayam dalam Bioremediasi Limbah Minyak Bumi Sistem Land Treatment
}

\section{Pujawati Suryatmana1), Richard A. Gunawan'2), Diyan Herdiyantoro'1), dan Mieke R. Setiawati1)}

\author{
1)Departemen Ilmu Tanah dan Sumberdaya Lahan, Fakultas Pertanian Universitas Padjadjaran \\ 2)Program Studi Agroteknologi, Fakultas Pertanian Universitas Padjadjaran \\ Jl. Raya Bandung Sumedang Km 21 Jatinangor \\ Korespondensi: pujawati@unpad.ac.id
}

\begin{abstract}
Bioremediation of petroleum waste using the land treatment system is generally carried out by indigenous Petrophilic stimulation as a degrading agent. One of the efforts to improve the performance of the bioremediation system is by adding petrophilic inoculants and organic material as a source of nutrition. This experiment focused on observation of the effect of endogenous petrophilic consortium by adding chicken manure compost towards bioremediation performance parameters, including the efficiency of hydrocarbon degradation, soil $p H$ and petrobacter population on Jatinangor Inceptisols contaminated with petroleum waste. The experiment Design used in this experiment was Factorial Randomized Block Design (FRBD). The first factor was the variation of the concentration of the petrophilic consortium, consisted of: (i) without a petrophilic consortium, (ii) the concentration of petrophilic consortium $1 \%(w / w)$, (iii) the concentration of petrophilic consortium 3\% ( $w / w$ ), (iv) concentration of petrophilic consortium $5 \%(w / w)$. The second factor was the variation of the concentration of chicken manure compost: (ii) without compost chicken manure, (ii) the concentration of chicken manure compost 1.5\% ( $w / w)$, and (iii) the concentration of chicken manure compost 3\% $(w / w)$. ). The results showed that the treatment of exogenous Petrophilic and chicken manure could not significantly improve the biodegradation efficiency of hydrocarbons, but the Petrophilic additives of $3 \%(w / w)$ could increase the highest Petrophilic population. From this study was found that indigenous petrophilic had the potential to degrade hydrocarbons by $71.20 \%$, while the application of exogenous $1 \%(w / w)$ petrophilic was able to degrade hydrocarbons by $71.97 \%$.
\end{abstract}

Keys worlds: Biodegradation, Bioremediation, Hydrocarbon, Petrophilic

\section{PENDAHULUAN}

Proses eksploitasi minyak bumi akan menghasilkan limbah yang dapat dikategorikan ke dalam Bahan Berbahaya dan Beracun (B3). Limbah lumpur minyak termasuk ke dalam daftar limbah B3 dari sumber spesifik dengan kode kegiatan 2320, maka pengelolaannya diperlukan penanganan secara tepat sehingga tidak mencemari lingkungan (BAPEDAL, 2001). Limbah minyak bumi dapat berpengaruh terhadap lingkungan dan kesehatan manusia bila tidak ditangani dengan baik dan tepat.

Salah satu upaya untuk mengolah limbah minyak bumi dapat dilakukan melalui pendekatan secara biologis yang dikenal bioremediasi (KLH, 2003). Bioremediasi merupakan suatu proses penguraian senyawa- senyawa hidrokarbon kompleks menjadi air, karbondioksida dan senyawa organik sederhana secara biologis. Pada proses tersebut terjadi proses oksidasi senyawa organik kompleks menjadi senyawa yang lebih sederhana (Udiharto dan Sudaryono, 1996). Kendala yang sering terjadi dalam proses degradasi Hidrokarbon dengan metode bioremediasi adalah efisiensi biodegradasi yang rendah. Oleh karena itu penambahan Mikroba pendegradasi eksogenous dengan dosis aplikasi yang tepat merupakan hal yang perlu dilakukan. Upaya peningkatan efektifitas mikroba pendegradasi eksogenous adalah dengan penambahan bahan organik yang tepat dengan dosis yanag tepat pula.

Sistem Bioremediasi yang digunakan dalam penelitian ini adalah metode 
landtreatment menggunakan isolat petrofilik dan pupuk organik sebagai sumber unsur nitrogen dan memperbaiki unsur hara tanah. Landtreatment merupakan teknik bioremediasi yang dilaksanakan di permukaan tanah baik secara in-situ maupun ex-situ. Teknik ini merupakan metode bioremediasi yang diterapkan dalam meremediasi tanah tercemar minyak bumi (Munawar, 2012). Mekanisme utama yang terlibat dalam kehilangan hidrokarbon di dalam sistem landfarming adalah terjadi proses biodegradasi, penguapan, oksidasi, dansampai batas tertentu terdegradasi oleh sinar mataharidan terjadi pencucian. Keunggulan sistem landfarming dibandingkan dengan sistem lain adalah lebih murah dalam segi biaya, dan juga aman untuk lingkungan (Bonnier et. al., 1980; El-Nawawy et. al., 1987).

Pada sistem bioremediasi land treatment diperlukan nutrisi yang $\mathrm{N}$ dan $\mathrm{P}$ dalam konsentrasi yang tepat. Biodegradasi hidrokarbon minyak bumi dalam tanah dipengaruhi oleh beberapa faktor antara lain temperatur, kadar air, bahan organik tanah, serta pasokan hara (pemupukan) (Pritchard dan Costa 1991; Bragg et. al., 1994; Margesin et. al., 2000; Van Hamme et. al., 2003). Untuk memenuhi kebutuhan $\mathrm{N}$ dan $\mathrm{P}$ yang cukup dalam sistem land treatment dapat digunakan pupuk organik. Morgan dan Watkinson (1989) menyatakan bahwa dalam proses biodegradasi rata-rata ditemukan $\mathrm{C} / \mathrm{N}$ pada hidrokarbon minyak bumi yaitu antara 9/1 dan $200 / 1$. Pemberian pupuk organik sebagai sumber $\mathrm{N}$ pada lahan tercemar minyak bumi diharapkan dapat menurunkan nilai $\mathrm{C} / \mathrm{N}$ minyak bumi.

Pupuk organik yang dapat digunakan untuk menyediakan nutrisi bagi kebutuhan $\mathrm{N}$, $\mathrm{P}$ dan $\mathrm{K}$ bagi aktifitas Petrofilik yang potensial adalah pupuk organic kotoran ayam karena kandungan karbonnya yang rendah dan nitrogen yang tinggi. Hal ini sangat potensial digunakan sebagai sumber $\mathrm{N}$ bagi sistem Bioremediasi untuk menguraikan hidrokarbon minyak bumi yang mencemari tanah dapat lebih efektif. Mengingat bahwa hidrokarbon minyak bumi memiliki $\mathrm{C} / \mathrm{N}$ yang tinggi, sehingga sulit terdegradsai oleh petrofilik. Proses biodegradasi hidrokarbon sendiri dipengaruhi oleh temperatur, $\mathrm{pH}$, kandungan air dan nutrisi yang tersedia (Udiharto dan Sudaryono, 1996).

Penggunaan mikrooorganisme indigenous (indigen) dalam proses bioremediasi land treatment masih memberikan hasilyang belum maksimal sehingga diperlukan inokulasi mikroorganisme eksogenous (eksogen) yang merupakan kultur campuran (konsorsium) beberapa jenis bakteri atau jamur yang potensial dalam mendegradasi pencemar tersebut (Udiharto dan Sudaryono, 1996). Kelompok mikroba yang sering digunakan dalam proses bioremediasi dan dominan ditemukan pada lingkungan hidrokarbon adalah bakteri petrofilik (Bossert dan Bartha, 1984), yaitu bakteri yang memiliki kemampuan mendegradasi senyawa hidro-karbon untuk keperluan metabolisme dan perkembangbiakannya disebut bakteri hidrokarbonoklastik atau bakteri petrofilik. Balteri ini mampu menghasilkan enzim yang berfungsi sebagai biokatalisator reaksi enzimatik proses biodegradasi hidrokarbon minyak bumi seperti alkana monooksidase, alkohol dehidrogenase, dan formaldehid dehidrogenase (Atlas dan Bartha, 1997).

Menurut Douglas et. al. (1992) kemampuan bakteri mendegradasi hidrokarbon berturut turut adalah n-alkana > alkana bercabang $>$ hidrokarbon aromatik > alkana siklik. Rosenberg et. al. (1996) menyebutkan bahwa berbagai mikroorga-nisme prokariotik dan eukariotik diketahui memiliki kemampuan untuk mengoksidasi hidrokarbon aromatik. Suryatmana (2006) mengemukakan bahwa Pseudomonas sp. dapat mendegradasi hidrokarbon alifatik rantai pendek seperti etena, propana, dan butana yang paling efektif dibanding Bacillus sp., Acinatebacter sp dan Enterobacter sp. Akan tetapi belum ditemukan dosis yang terbaik memberikan proses biodegradasi yang maksimal.

Tujuan penelitian ini adalah menemukan dan mempelajari dosis efektif dari petrobacter 
dan dosis pupuk kotoran ayam yang digunakan dalam meningkatkan efisiensi biodegradasi, meningkatkan populasi petrofilik dalam sistem land treatment skala mikrokosmos.

\section{METODOLOGI}

Percobaan dilaksanakan di Laboratorium Biologi Tanah, Departemen Ilmu Tanah, Fakultas Pertanian, Universitas Padjadjaran dan rumah kaca Kebun Percobaan Fakultas Pertanian, Universitas Padjadjaran pada ketinggian tempat $\pm 750 \mathrm{~m}$ diatas permukaan laut. Penelitian berlangsung selama 10 minggu.

\subsection{Rancangan Percobaan}

Rancangan percobaan yang digunakan adalah Rancangan Acak Kelompok (RAK) pola faktorial. Faktor pertama adalah konsentrasi konsorsium petrofilik yang terdiri dari 4 taraf, yaitu:

$$
\begin{aligned}
\mathrm{p} 0= & \text { tanpa konsorsium petrofilik }(\mathrm{w} / \mathrm{w}), \\
\mathrm{p} 1= & \text { konsentrasi konsorsium petrofilik } \\
& 1 \% \text { per beban limbah }(\mathrm{w} / \mathrm{w}) \\
\mathrm{p} 2= & \text { konsentrasi konsorsium petrofilik } \\
& 3 \% \text { per beban limbah }(\mathrm{w} / \mathrm{w}) \\
\mathrm{p} 3= & \text { konsentrasi konsorsium petrofilik } \\
& 5 \% \text { per beban limbah }(\mathrm{w} / \mathrm{w}) .
\end{aligned}
$$

Faktor ke-2 adalah konsentrasi pupuk kandang ayam, yang terdiri dari 3(tiga) taraf, yaitu:

$$
\begin{aligned}
\mathrm{k} 0= & \text { tanpa pupuk kandang ayam } \\
\mathrm{k} 1= & \text { konsentrasi pupuk kandang ayam } \\
& 1,5 \%(\mathrm{w} / \mathrm{w}) \\
\mathrm{k} 2= & \text { konsentrasi kompos kotoran ayam } \\
& 3 \% \text { per berat media }(\mathrm{w} / \mathrm{w}) .
\end{aligned}
$$

Kedua faktor perlakuan tersebut diulang sebanyak 3 kali ulangan.

\subsection{Tahap Persiapan}

Tanah yang digunakan dalam percobaan berasal dari lapisan top soil pada kedalaman sampai $20 \mathrm{~cm}$. Tanah yang sudah diolah dimasukkan ke dalam mikrokosmos yang berukuran panjang $30 \mathrm{~cm}$, lebar $25 \mathrm{~cm}$, dan tinggi $25 \mathrm{~cm}$ masing-masing sebanyak $2 \mathrm{~kg}$ per mikrokosmos yang dikontaminasi dengan $10 \%$ minyak mentah diaduk secara homogen.

Kultur cair konsorsium petrofilik berumur 24 jam diinokulasikan ke dalam carier padat (dedak : pupuk kandang ayam dengan perbandingan $1: 1$ ) sebanyak $10 \%$, diaduk rata hingga homogen. Kemudian diinkubasikan selama 1 minggu.

\subsection{Aplikasi Perlakuan}

Inokulan konsorsium petrofilik diaplikasikan sesuai perlakuan masing-masing 1\%, 3\% dan 5\% per konsentrasi beban limbah (w/w). Sedangkan konsentrasi kompos kotoran ayam yang diaplikasikan masing-masing adalah $1,5 \%$ dan $3 \%$ per $2 \mathrm{~kg}$ bobot $\operatorname{tanah}(\mathrm{w} / \mathrm{w})$. Mikrokosmos yang berisi tanah yang terkontaminasi minyak mentah sesara $10 \%$ yang sudah disiapkan tersebut dicampur langsung dengan masing-masing perlakuan konsorsium petrofilik dan pupuk kandang sesuai dengan konsentrasi perlakuan yang sudah ditetapkan dan dicampur secara merata. Selanjutnya dilakukan penyiraman pada kelembaban $60 \%$ kadar air kapasitas lapang.

\subsection{Analisis Laboratorium}

Analisis populasi metode Dillution (pengenceran secara seri) sampai dengan pengenceran $10^{-6}$.Satu $\mathrm{ml}$ larutan sampel tanah diinokulasikan pada medium Basal Hydrocarbon (BH) dalam cawan petri steril dan dikocok homogeny secara homogen, selanjutnya diinkubasi pada suhu $30^{\circ} \mathrm{C}$. Koloni yang tumbuh dihitung dengan menggunakan colony counter.

Analisis total petroleum hydrocarbon (TPH) dilaksanakan pada awal dan akhir percobaan, selang waktu 2 bulan. Sampel tanah komposit diambil sebanyak $5 \mathrm{~g}$ dan diekstraksi menggunakan n-heksan. Dengan perbandingan 1:2 antara sampel tanah : nheksan. Proses ektraksi dilakukan dengan cara mengocok sampel tanah terkonta-minasi yang telah ditambah n-Heksan pada alat pengocok 
dengan agitasi 100 rpm. Proses ektraksi diulang sebanyak 3 kali berturut sampai diperoleh larutan heksan dalam sample tanah berwarna bening. Ekstrak yang diperoleh dari masing-masing pelarut digabungkan dan ditimbang sebagai TPH secara gravimetri (modifikasi Suryatmana, 2006).

\section{HASIL DAN PEMBAHASAN}

\subsection{Suhu dan Kelembaban Tanah}

Suhu dan kelembaban tanah selama percobaan berlangsung berfluktuasi seperti yang dapat dilihat pada Gambar 1. Degradasi minyak bumi berlangsung dalam kisaran suhu yang luas, tetapi tidak selalu menjadi faktor utama yang membatasi biodegradasi, apabila faktor lingkungan lain cukup baik (Atlas dan Bartha, 1997). Pada percobaan ini suhu berada pada nilai antara $24,7^{\circ} \mathrm{C}$ hingga $33^{\circ} \mathrm{C}$, kisaran tersebut mengindikasikan bahwa mikroorganisme konsorsium petrofilik yang berada dalam percobaan tersebut hidup pada temperatur normal. Menurut Udiharto dan Sudaryono (1996) berdasarkan suhu lingkungannya bakteri dapat digolongkan menjadi 3 kelompok, yaitu: (i) psikrofilik memerlukan suhu optimum antara $5-15^{\circ} \mathrm{C}$, (ii) mesofilik memerlukan suhu optimum antara 25-40 ${ }^{\circ} \mathrm{C}$, dan (iii) thermofilik memerlukan suhu optimum antara $45-60{ }^{\circ} \mathrm{C}$, sedangkan suhu optimum untuk mendapatkan laju biodegradasi yang tinggi antara $30-40^{\circ} \mathrm{C}$.

Kelembaban tanah dalam percobaan ini berada pada kisaran 43,3-68,7\% (Gambar 1). Kandungan air sangat penting untuk aktivitas metabolik dari mikoba pada limbah minyak bumi karena mikroba akan hidup aktif di interfase antara minyak dan air (Udiharto dan Sudaryono, 1996). Suhu dan kelembaban tanah yang berfluktuasi selama penelitian menyebabkan kondisi optimum yang stabil tidak tercapai.

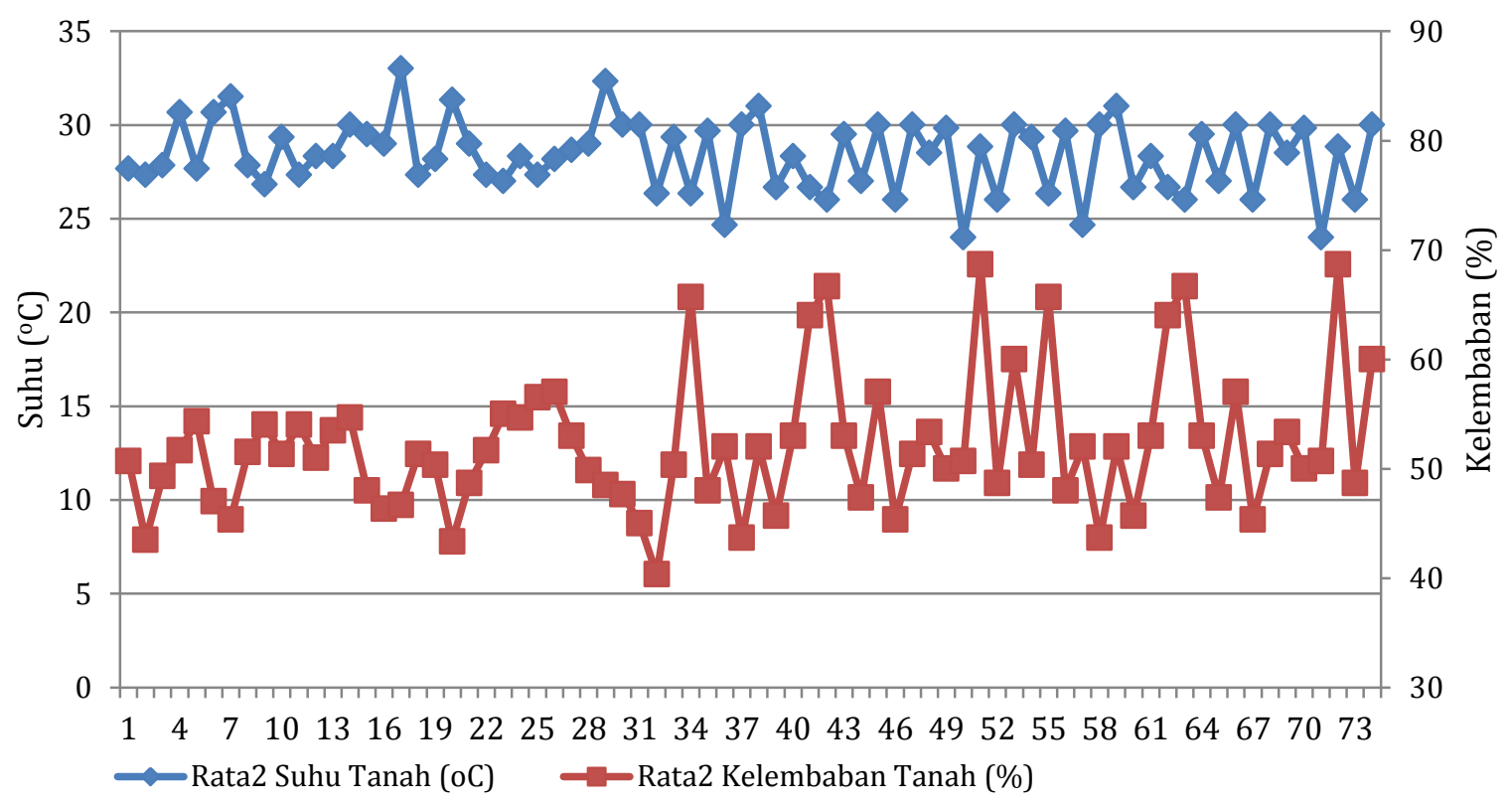

Gambar 1 Kurva Fluktuasi Suhudan Kelembaban Tanah selama Percobaan

\subsection{Reaksi Tanah (pH)}

Hasil pengamatan dan analisis ragam efisiensi degradasi hidrokarbon yang terjadi sampai minggu ke-10 menunjukkan bahwa tidak terdapat interaksi antara perlakuan konsentrasi konsorsium petrofilik dengan konsentrasi kompos kotoran ayam ataupun pengaruh mandiri masing-masing faktor terhadap penurunan $\mathrm{pH}$ (Tabel 1).

Tabel 1 menunjukkan bahwa berbagai perlakuan konsentrasi petrofilik maupun berbagai perlakuan konsentrasi pupuk 
kandang ayam tidak berpengaruh terhadap penurunan nilai $\mathrm{pH}$ tanah. Menurut Udiharto dkk (1995) selama aktivitas biodegradasi hidrokarbon minyak bumi berlangsung terjadi aktifitas bakteri mengeluarkan metabolitmetabolit ke dalam media berupa asam, surfaktan dan gas yang dapat mempengaruhi lingkungan sekitarnya, diantaranya asam yang dapat menurunkan $\mathrm{pH}$ dan surfaktan menurunkan tegangan antar muka media.

Tabel 1 Pengaruh konsentrasi petrofilik dan kompos kandang ayam terhadap $\mathrm{pH}$ tanah selama inkubasi 10 minggu

\begin{tabular}{cc}
\hline Perlakuan & pH Tanah \\
\hline p0 & 6,7 \\
p1 & 6,7 \\
p2 & 6,6 \\
p3 & 6,5 \\
k0 & 6,7 \\
k1 & 6,6 \\
k2 & 6,6 \\
\hline
\end{tabular}

Keterangan: Angka yang tidak diberi notasi huruf, tidak dilakukan uji lanjut jarakberganda Duncan karena tidak berbeda nyata berdasarkan analisis ragam pada taraf nyata $5 \%$.

Hasil analisis tanah awal menunjukkan bahwa Inceptisols yang digunakan sebagai media bioremediasi mengandung bahan organik yang sedang (data tidak ditampilkan). Bahan organik mempunyai kapasitas penyangga tanah (buffering capacity). Menurut Tan (1982) kapasitas penyangga tanah didefinisikan sebagai sesuatu yang menangkal perubahan $\mathrm{pH}$ akibat penambahan asam maupun basa sehingga konsentrasi ion $\mathrm{H}^{+}$tetap bertahan. Jumlah bahan organik tanah dengan kriteria sedang tersebut diduga dapat mempertahankan $\mathrm{pH}$ tanah tetap di sekitar netral walaupun dihasilkannya asamasam organik hasil aktivitas mikroba dalam proses biodegradasi hidrokarbon minyak bumi.

Hasil percobaan pada Tabel 1 menunjukkan bahwa dinamika perubahan $\mathrm{pH}$ karena pengaruh perlakuan berkisar antara 6,5 - 6,7. Menurut Udiharto (1996) mikroorganisme pada umumnya tumbuh dengan baik pada $\mathrm{pH}$ antara 6,0-8,0, sedangkan secara tidak langsung $\mathrm{pH}$ tanah mempengaruhi kenaikan atau penurunan ketersedian nutrisi khususnya fosfor (Bewley, 1996).

\subsection{Populasi Petrobacter}

Hasil analisis ragam terhadap populasi petrobacter pada akhir pecobaan menunjukkan bahwa terdapat interaksi antara aplikasikonsorsium petrofilik dengan kompos kotoran ayam terhadap peningkatan populasi petrobacter (Tabel 2).

Tabel 2 Pengaruh Konsentrasi Petrofilik dan Kompos Kotoran Ayam terhadap Populasi Petrobacter (x $10^{6} \mathrm{cfu} / \mathrm{g}$ ) Selama Inkubasi 10 Minggu.

\begin{tabular}{|c|c|c|c|}
\hline Perlakuan & $\mathrm{k}_{0}$ & $\mathrm{k}_{1}$ & $\mathrm{k}_{2}$ \\
\hline $\mathrm{p}_{0}$ & $\begin{array}{c}9,26 \mathrm{~A} \\
\mathrm{a}\end{array}$ & $\begin{array}{c}21,17 \mathrm{~A} \\
\mathrm{~b}\end{array}$ & $\begin{array}{c}19,73 \mathrm{~A} \\
\mathrm{~b}\end{array}$ \\
\hline $\mathrm{p}_{1}$ & $\begin{array}{c}19,20 \mathrm{~B} \\
\mathrm{a}\end{array}$ & $\begin{array}{c}19,27 \mathrm{~A} \\
\mathrm{a}\end{array}$ & $\begin{array}{c}21,53 \mathrm{~A} \\
\mathrm{a}\end{array}$ \\
\hline $\mathrm{p}_{2}$ & $\begin{array}{c}25,06 \mathrm{C} \\
\mathrm{a}\end{array}$ & $\begin{array}{c}21,38 \mathrm{~A} \\
\mathrm{ab}\end{array}$ & $\begin{array}{c}24,53 \mathrm{~A} \\
\mathrm{a}\end{array}$ \\
\hline $\mathrm{p}_{3}$ & $\begin{array}{c}24,90 \mathrm{C} \\
\mathrm{a}\end{array}$ & $\begin{array}{c}23,13 \mathrm{~B} \\
\mathrm{a}\end{array}$ & $\begin{array}{c}17,50 \mathrm{~A} \\
\mathrm{a}\end{array}$ \\
\hline \multicolumn{4}{|c|}{$\begin{array}{l}\text { Angka yang diikuti oleh huruf yang sama } \\
\text { tidak berbeda nyata berdasarkan uji } \\
\text { lanjutjarak berganda Duncan pada taraf } \\
\text { nyata } 5 \% \text {. Huruf kecil dibaca ke arah } \\
\text { horizontal dan huruf kapital dibaca ke } \\
\text { arah vertikal. }\end{array}$} \\
\hline
\end{tabular}

Hasil penelitian juga menunjukkan bahwa perlakuan konsorsium petrofilik 3\% dan tanpa pupuk kandang ayam $\left(\mathrm{p}_{2} \mathrm{k}_{0}\right)$ memiliki total populasi petrobacter tertinggi dibandingkan dengan perlakuan lainnya. Hal ini menunjukkan bahwa pemberian konsentrasi konsorsium petrofilik 3\% jumlah inokulannya sudah dapat bertahan di lingkungan tanah tercemar minyak bumi tersebut. Jumlah inokulan konsorsium petrofilik yang diinokulasikan mampu memanfaatkan faktor-faktor lingkungan dengan baik dan mampu beradaptasi pada lingkungan tercemar minyak bumi meskipun tanpa penambahan kompos kotoran ayam. Akan tetapi meskipun populasi petrofilik 
meningkat pada konsentrasi 3\% per beban limbah namun belum mampu memberikan peningktatan terhadap kinerja biodegradasi limbah minyak bumi, terbukti efisiensi biodegradasi tidak meningkat (Tabel 3).

Proses biodegradasi senyawa hidrokarbon minyak bumi dipengaruhi oleh beberapa faktor utama yaitu bakteri petrofilik yang melakukan biodegradasi, faktor lingkungan selama proses biodegradasi, dan nutrien yang dibutuhkan. Jenis-jenis bakteri petrofilik dapat secara maksimal melakukan degradasi jika faktor lingkungan yang ada sesuai dan nutrien yang dibutuhkan terpenuhi (Munawar dan Said, 2007; Munawar, 2012).

Dalam penelitian ini suhu dan kelembaban berfluktuasi dengan rentang nilai yang cukup lebar (Gambar 1), hal ini dapat mengakibatkan aktifitas petrobacter dalam mendegradasi hidrokarbon minyak bumi menjadi kurang efektif meskipun populasi cenderung meningkat.

\subsection{Efisiensi Degradasi Hidrokarbon}

Hasil pengamatan dan analisis ragam terhadap efisiensi degradasi hidrokarbon yang terjadi sampai minggu ke-10 (Tabel 3) menunjukkan bahwa tidak terdapat interaksi antara aplikasi variasi petrofilik dengan pupuk kotoran ayam terhadap peningkatan efisiensi degradasi hidrokarbon. Jika dianalisis secara mandiri, aplikasi petrofilik berpengaruh terhadap peningkatan efisiensi degradasi hidrokarbon.

Tabel 3 menunjukkan bahwa perlakuanperlakuan tanpa konsorsium petrofilik $\left(\mathrm{p}_{0}\right)$, konsentrasi konsorsium petrofilik 1\% $\left(\mathrm{p}_{1}\right)$ dan konsentrasi konsorsium petrofilik 5\% $\left(\mathrm{p}_{3}\right)$ memberikan nilai efisiensi biodegradasi hidrokarbon yang cenderung lebih tinggi ddibandingkan dengan perlakuan konsentrasi konsorsium petrofilik3\% $\left(\mathrm{p}_{2}\right)$ yaitu sebesar $71,97 \%$. Hal ini menunjukkan bahwa dengan penambahan konsentrasi konsorsium petrofilik tidak memberikan efek terhadap peningkatan proses biodegradasi sampai minggu ke 10. Hal ini terjadi karena inokulan petrofilik yang diinokulasikan merupakan inokulan yang terdiri dari lebih dari satu spesies yang dapat mengakibatkan terjadinya interaksi yang negatif diantara konsorsium dan persaingan sumber Karbon dan nutrisi.

Tabel 3 Pengaruh konsentrasi petrofilik dan kompos kotoran ayam terhadap efisiensi degradasi hidrokarbon selama inkubasi 10 minggu

\begin{tabular}{|c|c|}
\hline Perlakuan & $\begin{array}{c}\text { Efisiensi Degradasi } \\
\text { Hidrokarbon (\%) }\end{array}$ \\
\hline p0 & $71,20 \mathrm{~b}$ \\
\hline $\mathrm{p} 1$ & $71,97 b$ \\
\hline p2 & $57,18 \mathrm{a}$ \\
\hline p3 & $68,44 b$ \\
\hline k0 & $67,69 a$ \\
\hline $\mathrm{k} 1$ & $67,30 a$ \\
\hline k2 & $66,60 \mathrm{a}$ \\
\hline \multicolumn{2}{|c|}{$\begin{aligned} \text { Keterangan: Angka yang diikuti oleh huruf yang sama } \\
\text { tidak berbeda nyata berdasarkan uji } \\
\text { lanjut jarak berganda Duncan pada taraf } \\
\text { nyata 5\%. Angka yang tidak diberi notasi } \\
\text { huruf, tidak dilakukan uji lanjut jarak } \\
\text { berganda Duncan karena tidak berbeda } \\
\text { nyata berdasarkan analisis ragam pada } \\
\text { taraf nyata 5\%. }\end{aligned}$} \\
\hline
\end{tabular}

Penambahan kompos kotoran ayam sampai $3 \%$ belum dapat menyediakan nutrisi $\mathrm{N}$ yang cukup untuk meningkatkan aktifitas degradasi hidrokarbon yang ada. Petrofilik indigen memiliki kemampuan mendegradasi hidrokarbon sebesar $71,20 \%$ tidak berbeda nyata dengan perlakuan petrofilik eksogen. Pada minggu ke 10 proses biodegradasi oleh petrofilik akan menghasilkan senyawa intermediate (senyawa antara) yang kemungkinan lebih toksik, dan juga adanya residu hidrokarbon yang resisten didegradasi oleh petrofilik eksogenpous, sehingga mengakibatkan efisiensi biodegradasi tidak berbeda nyata dengan kontrol, bahkan pada dosis 3\% per beban limbah efisiensi biodegradasi menurun secara signifikan.

Berdasarkan hasil pengamatan, terbukti bahwa petrofilik indigen memiliki potensi yang tidak berbeda nyata dengan Petrofilik eksogen yang ditambahkan. Leahy dan Colwell 
(1990) menyatakan bahwa kemampuan tumbuh dari mikroorganisme yang mendegradasi minyak bumi berbeda-beda tergantung adaptasi mikroorganisme tersebut terhadap lingkungannya.

Faktor mandiri akibat perlakuan variasi konsentrasi kompos kotoran ayam juga tidak berpengaruh nyata terhadap nilai efisiensi biodegradasi hidrokarbon (Tabel 3). Tujuan diberikannya kompos kotoran ayam adalah untuk menurunkan $\mathrm{C} / \mathrm{N}$ tanah terkontaminasi, mengingat minyak bumi memiliki $\mathrm{C} / \mathrm{N}$ yang sangat tinggi sehingga dalam kondisi tersebut proses biodegradasi tidak berjalan optimal. Seperti diketahui bahwa pupuk kandang ayam merupakan pupuk kandang yang kaya mengandung N. Menurut Widodo (2008) kotoran ayam merupakan bahan organik sumber nitrogen tanah, serta berperan cukup besar dalam memperbaiki sifat fisik, kimia, dan biologi tanah serta lingkungan sehingga diharapkan dapat menurunkan $\mathrm{C} / \mathrm{N}$ minyak bumi.

Dalam percobaan ini faktor mandiri konsentrasi pupuk kotoran ayam dalam meningkatkan efisiensi biodegradasi minyak bumi tidak berpengaruh nyata, hal ini diduga karena dosis yang diberikan belum dapat memenuhi kisaran dosis yang dibutuhkan untuk memacu aktivitas petrofilik, sehingga tujuan pemberian kompos kotoran ayam untuk meningkatkan proses biodegradasi tidak tercapai.

\section{KESIMPULAN}

Kondisi suhu tanah percobaan pada beban limbah sebesar 10\% menunjukkan fluktuali nilai pada kisaran $24,7^{\circ} \mathrm{C}$ hingga $33^{\circ} \mathrm{C}$ dan Kelembaban tanah berkisar 43,3-68,7\%. Kondisi lingkungan ini mengakibatkan aktivitas petrobacter tidak optimal. Sedangkan kemasam tanah $(\mathrm{pH})$ cenderung stabil pada kisaran 6,6 - 6,7. Penambahan Petrofilik eksogen sebesar 3\% (w/w) mengakibtakan meningkatnya populasi petrofilik total pada akhir pengamatan, dan pertambahan populasi petrofilik tidak dipengaruhi oleh penambahan kompos kotoran ayam, sehingga dari hasil analisis tampak bahwa antar penggunaan petrofilik eksogen dan kompos kotoran ayam tidak menunjukkan interaksi terhadap efisiensi biodegradasi. Petrofilik Indigen dan eksogen memiliki potensi yang tidak berbeda nyata dalam mendegradasi Hidrokarbon minyak bumi yaitu masing masin sebesar $71,97 \%$ dan $71,20 \%$.

\section{Ucapan Terimaksih}

Terima kasih kepada Kementerian Riset dan Teknologi dan Pendidikan Tinggi (Kemenristek Dikti) yang telah mendanai penelitian ini pada implementasi skema program Penelitian Dasar Unggulan Perguruan Tinggi (PDUPT) tahun anggaran 2019, serta terimaksih pada Kepala Laboratorium Biologi Tanah Departemen Ilmu Tanah, Universitas Padjadjaran yang telah membantu untuk menyediakan fasilitas laboratorium selama masa penelitian berlangsung.

\section{DAFTAR PUSTAKA}

Atlas R.M, Bartha R. 1997. Microbial Ecology: Fundamentals and Applications $4^{\text {th }}$ ed. California: Benjamin Cumming Publishing, Co. Inc.

BAPEDAL (Badan Pengendalian Dampak Lingkungan). 2001. Peraturan RI Nomor 41 Tahun 1999 Tentang Pengendalian Pencemaran Udara. Jakarta.

Bewley J.F. 1996. Field implementation of in situ bioremediation: key physiscochemical and biological factors. In Stozky G and Bollag, J.M (Eds) Soil Biochemistry Vol.9. Marcel Dekker. pp.475-555.

Bonnier P.D, Akoun G.L, Cadron E.C, Dewards E.D, Hockness W.A. 1980. Sludefarming: a technique for disposal of oil refinery waste. Report No. 3/10. Concawe: The Hague.

Bossert, I and Bartha, R. 1984. The fate of petroleum in soil ecosystems. In Atlas 
R.M (Ed)Pe troleum Microbiology. Macmillan, New York. pp: 435-476.

Bragg J.R., R.C. Prince, E.J. Harner, and R.M. Atlas.1994. Effectiveness of bioremediation for the Exxon Valdes oil spill. Nature 368 (6470): 413-418.

Douglas G.S, K.J. Mc Carthy, D.T Dahlen, J.A Seavey, W.G. Steinhauer, R.C. Prince, and D.L. Elmendorf. 1992. The use of hydrocarbon analyses for environmental assesment and remediation. Journal of Soil Contaminant 1(3):197 - 216.

El-Nawawy A.S, Ghobrial F, Eliman A. 1987. Feasibility study of disposal of oily sludge in Kuwait. In Proceedings of the $2^{\text {nd }}$ International Conference on New Frontiers for Hazardous Waste Management, Pittsburgh, PA, 27-30 September. pp 162-168.

Eweis J, S.J. Ergas, Sarina J, D.P.Y. Chang, and E.D Schroeder. 1998. Bioremediation Principles.Wiliam C Brown Pub, USA.

[KLH] Kementrian Lingkungan Hidup. 2003. Tatacara dan Persyaratan Teknis Pengolahan Limbah Minyak Bumi dan Tanah Terkontaminasi oleh minyak Bumi secara Biologis. Keputusan Kementrian Lingkungan Hidup No. 128 Tahun 2003. Jakarta: Kementerian Lingkungan Hidup.

Leahy J.G and ColwellR.R. 1990. Microbial degradation of hydrocarbon in the evvironment. Microbiological Reviews 54(3): $305-315$.

Margesin R, A. Zimmerbauer, and F. Schinner. 2000. Monitoring of bioremediation by biological activities. Chemosphere 40(4): 339-346.

Morgan P, and Watkinson R.J. 1989. Hydrocarbon degradation in soils and method for soil biotreatment. Critical Reviews in Biotechnology 8(4): 305333.

Munawar dan Said M. 2007. Role of nutrient and bacteria in reduction of oil in bioremediation of waste water from oil refinery industry. In Proceedings of the $14^{\text {th }}$ regional symposium chemical enginerring. Yogyakarta: Universitas Gadjah Mada.
Munawar. 2012. Bioremediasi Tanah Terkontaminasi Minyak Bumi oleh Konsorsium Bakteri Petrofilik, Penambat Nitrogen dan Pelarut Fosfat [Disertasi]. Institut Teknologi Bandung, Bandung.

Pritchard P.H and Costa C.F. 1991.EPA's Alaska oil spill bioremediation project.Environmental Science and Technology25(3): 372-379.

Rosenberg E, R. Legman, A. Kushmaro, R. Taube, E. Adler, E.Z Ron. 1992. Petroleum bioremediation - a multiphase problem. Biodegradation 3: 337-350.

Suryatmana P. 2006. Biodegradasi Hidrokarbon Minyak Bumi dengan Penambahan Azotobacter chroococcum AC04 sebagai Bakteri Penghasil Biosurfaktan.Disertasi. Institut Teknologi Bandung, Bandung.

Tan K.H. 1982. Principles of Soil Chemistry $4^{\text {th }}$ Edition. CRC Press, New York.

Udiharto M, S.A Rahayu, A. Haris, Zulkifliani R. 1995. Peran bakteri dalam degradasi minyak dan pemanfaatannya dalam penanggulangan minyak buangan. Dalam : Prosiding Diskusi Ilmiah VIII PPPTMGB Lemigas, Jakarta.

Udiharto M, dan Sudaryono. 1996. Bioremediasi terhadap tanah tercemar minyak bumi parafinik dan aspal. Dalam Prosiding Seminar Nasional Teknologi Pengelolaan Limbah dan Pemulihan Kerusakan Lingkungan-BPPT, Jakarta. Hal: 121132.

Van Hamme J.D, A Singh, and O.P Ward. 2003. Recent advances in petroleum microbiology. Microbiology and Moecular Biology Reviews. 67(4): 503-549.

Widodo A. 2008. Pupuk Organik dan Pupuk Hayati. Balai Besar Sumberdaya Lahan Pertanian, Bogor.

Wrenn B.A, J.R. Haines, A.D. Venosa, M. Kadkhodayan, M.T.Suidan. 1994. Effects of nitrogen source on crude oil biodegradation. Journal of Industrial Microbiology 13(5):279-286. 